\author{
Пустюльга С.І., Пуць В.С., Клак Ю.В. \\ Луиький начіональний технічний університет
}

\title{
БАГАТОКРИТЕРІАЛЬНА ОПТИМІЗАЦІЯ РОЗКРОЮ ПЛИТ ЛДСП ДЛЯ ІНДИВІДУ АЛЬНОГО МЕБЛЕВОГО ВИРОБНИЦТВА
}

\begin{abstract}
Дана робота присвячена розробці ефективних алгоритмів для розв'язку багатокритеріальних оптимізаційних задач розкрою плит ЛДСП (ламінована деревно-стружкова плита) на підприємствах із виготовлення меблів за індивідуальним замовленням.

Відома значна кількість спеціалізованих програм розкрою, що активно застосовуються на меблевому виробництві. Практично всі вони, в тій чи іншій мірі, є уніфікованими програмами створення карт розкрою, що поєднують у собі оптимальність розташування контурів деталей в заданих габаритах вихідного матеріалу із потрібною швидкістю розрахунків. В основу роботи більшості цих програм покладено підхід із використання певних математичних алгоритмів, що дозволяють ефективно провести розкрій із мінімальною кількістю відходів.

Однак, виходячи із особливостей саме одиничного меблевого виробництва, оптимальним варіантом слід визнати такий автоматизований підхід до формування карт розкрою матеріалів, який дозволив би виробнику враховувати якнайбільше критеріїв оптимізації розміщення елементів, гнучко керувати пріоритетами важливості їх врахування, формувати оптимальні карти відповідно технологічним можливостям устаткування, що працює на даному виробництві (параметри пил, степінь свободи і поворотність столів, наявність спеціальних пристосувань для фіксації листів і т. і.). Врахування вищенаведених виробничих функцій жодна із перелічених програм забезпечити не здатна.

У роботі, на основі аналізу стандартних етапів та можливостей програм комп'ютерного розрахунку раціонального розкрою матеріалів, запропоновано методику та алгоритми розв'язку задач багатокритеріальної оптимізації розкрою листів ЛДСП на елементи різної геометричної форми для виробництва меблів індивідуального замовлення. Визначено особливості постановки та критерії задачі багатокритеріальної оптимізації, які дозволяють швидко і ефективно аналізувати якість отриманих на першому етапі карт розкрою, коригувати значущість і пріоритетність кожного із вибраних критеріїв оптимізації. Удосконалено алгоритм пошуку початкового базисного розв'язку задачі лінійного програмування, який суттєво скоротив кількість ітерацій в розрахунковій схемі та спростив процедуру розрахунку. Проведено комп'ютерну реалізацію розроблених алгоритмів. Перевірено ефективність запропонованої методики та алгоритмів для виробництва продукції на підприємстві із виготовлення меблів за індивідуальним замовленням.

Ключові слова: раціональний розкрій матеріалів, багатокритеріальна оптимізація, парето-оптимальні рішення, лінійне програмування, критерії задачі оптимізації.
\end{abstract}

\section{ВСТУП}

Побудова оптимальних карт розкрою матеріалу є одним із найбільш трудомістких етапів будь-якого виробництва. У той же час якісне виконання розкрою є достатньо важливим для усіх галузей промисловості, оскільки безпосередньо веде до економії матеріалу та зниження відходів, а від так виступає гарантом економічної прибутковості.

На сьогодні, для вирішення завдання ефективного розкрою матеріалу активно використовуються усі можливості сучасних ЕОМ. Це дозволило значно прискорити та спростити процес генерації карт розкрою у порівнянні із неавтоматизованими методами [1], [2]. Особливо активно програми для генерації карт раціонального розкрою матеріалів впроваджуються на підприємствах із проектування та виробництва меблів під індивідуальні замовлення. Пов'язано це передусім із тим, що завдання розкрою для таких підприємств відноситься до одиничних завдань, а отже $€$ найгострішою проблемою налаштування ефективного і прибуткового виробництва.

\section{АНАЛІЗ ЛІТЕРАТУРНИХ ДАНИХ ТА ПОСТАНОВКА ПРОБЛЕМИ}

Відома значна кількість спеціалізованих програм розкрою, що активно застосовуються на меблевому виробництві. До них можна віднести: Acтра-розкрій, bCAD-Мебляр, Розкрій, Базисрозкрiü, Cutting, Pane Cut, NCL, Optimum, Базис-Мебляр та інші [1]-[4]. Практично всі вони, в тій чи іншій мірі, $є$ уніфікованими програмами створення карт розкрою, що поєднують у собі оптимальність розташування контурів деталей в заданих габаритах вихідного матеріалу із потрібною швидкістю розрахунків. А в основу роботи більшості цих програм покладено підхід із використання певних математичних алгоритмів, що дозволяють ефективно провести розкрій із мінімальною кількістю відходів.

Однак, виходячи із особливостей саме одиничного меблевого виробництва, оптимальним варіантом слід визнати такий автоматизований підхід до формування карт розкрою матеріалів, який 
дозволив би виробнику враховувати якнайбільше критеріїв оптимізації розміщення елементів, гнучко керувати пріоритетами важливості їх врахування, формувати оптимальні карти відповідно технологічним можливостям устаткування, що працює на даному виробництві (параметри пил, степінь свободи і поворотність столів, наявність спеціальних пристосувань для фіксації листів і т. і.). Врахування вищенаведених виробничих функцій жодна із перелічених програм забезпечити не здатна. Від так, актуальними є дослідження по удосконаленню існуючих алгоритмів розв'язання оптимізаційних задач розкрою, які можна віднести до багатокритеріальних задач лінійного програмування.

Упродовж останніх 20 років дослідженням в області розкрою і розробки нових алгоритмів генерації карт укладання плоских деталей на листах відповідного розміру було присвячено безліч вітчизняних і зарубіжних робіт, наприклад [5]-[12]. Огляд цих робіт показав, що в них ставилися та вирішувалися питання оптимізації розкрою листових матеріалів на елементи, як правило прямокутної форми, тільки за одним критерієм. Аналіз літературних джерел вказав на відсутність загального підходу та алгоритмів розв'язання саме багатокритеріальних задач розкрою із визначеними коефіцієнтами впливу різних критеріїв.

3 іншого боку, з'являються проблеми із алгоритмами оптимізації карт, коли елементи розкрою мають геометричну форму відмінну від прямокутної. У даній роботі зроблена спроба узагальнити підхід до розв'язання багатокритеріальної задачі оптимізації розкрою із елементами, що мають відмінну від прямокутної геометричну форму, оскільки це є важливою проблемою саме одиничного виробництва.

\section{ЦІЛЬ ТА ЗАДАЧІ ДОСЛІДЖЕННЯ}

Дана робота ставить за мету розробку підходів та ефективного алгоритму пошуку множини парето-оптимальних розв'язків багатокритеріальних оптимізаційних задач розкрою плит ЛДСП (ламінована деревно-стружкова плита) на підприємствах із виготовлення меблів за індивідуальним замовленням. На основі введення множини критеріїв якості розміщення елементів необхідно розробити методику визначення найкращого вектору розв'язку задачі розкрою без втручання експертів та технологів на виробництві. Для досягнення поставленої мети вирішувалися наступні задачі:

- проаналізувати стандартні етапи та спеціалізовані програми раціонального розкрою листів ЛДСП на підприємствах із виробництва меблів;

- розробити критерії та загальний підхід до розв'язання задачі багатокритеріальної оптимізації, який дозволив би швидко і ефективно аналізувати якість, отриманих на першому етапі карт розкрою, відповідно визначеним критеріям оптимізації, коригувати їх значущість i пріоритетність;

- удосконалити алгоритм пошуку початкового базисного розв'язку задачі лінійного програмування, що дозволив би суттєво скоротити кількість ітерацій симплекс-методу, а значить спростити процес розрахунку;

- провести комп'ютерну реалізацію розроблених алгоритмів.

\section{РЕЗУЛЬТАТИ ДОСЛІДЖЕНЬ}

Проектування карт розкрою листів ЛДСП на переважній більшості підприємств із одиничного меблевого виробництва за допомогою спеціалізованих комп'ютерних програм, як правило, зводиться до двох етапів. На першому етапі будується декілька можливих карт розкрою, що задовольняють певним заданим критеріям (рис. 1 а, б. в), на другому - із цієї множини, емпіричним шляхом, визначається краща карта.

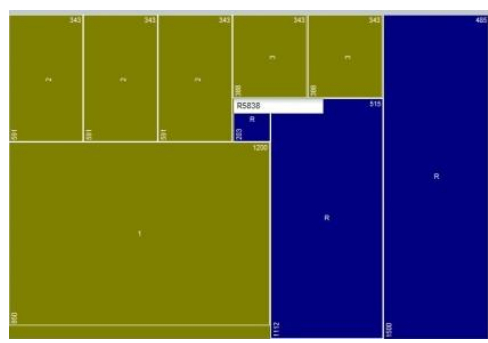

a

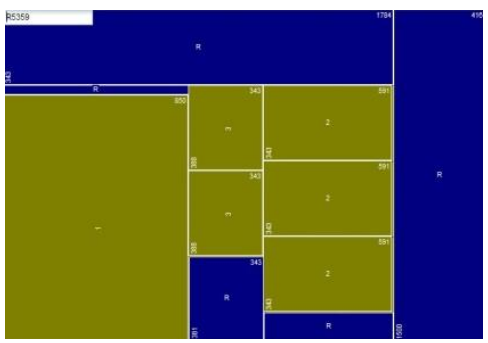

6

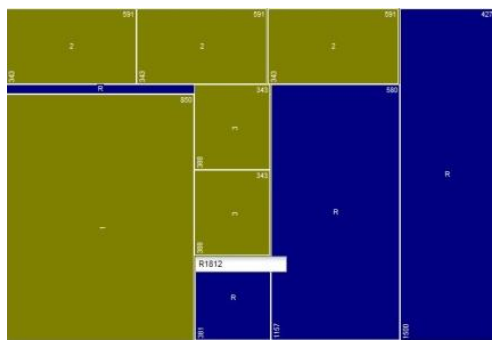

B

Рисунок 1 - Варіанти карт розкрою для виробництва одного виробу 
Відповідно до цього, у процесі розрахунку розкрою можна виділити два основні класи завдань для виробництва. Перший клас - це завдання геометричного моделювання на ЕОМ, в ході виконання якого вирішується питання розміщення потрібних деталей на листі і отримання карти розкрою. Реалізацію завдання такого роду забезпечують, у тій чи іншій мірі, практично всі спеціалізовані програми розкрою, хоча слід зазначити, що це безперебійно працює при розкрою листів на деталі тільки прямокутної форми.

Другий клас завдань представляє собою розв'язання чисто оптимізаційних задач, які, у більшості випадків, на виробництві взагалі не враховуються (емпіричні методи простого перебору не беруться до уваги).

Ми пропонуємо, на даному етапі, запровадити простий алгоритм багатокритеріальної оптимізації (БО), який дозволятиме швидко і ефективно аналізувати отримані на першому етапі карти розкрою за визначеними критеріями оптимізації, коригувати їх значущість і пріоритетність, а отже генерувати ті карти розкрою, які будуть найбільш раціональними для виробництва за даних умов.

Виходячи із результатів, отриманих у роботах [17], [18], можна констатувати, що багатокритеріальні задачі оптимізації, як правило, не мають «ідеального розв'язку». Відтак, практично неможливо досягти в задачах оптимуму у одній і тій же точці за набором всіх визначених критеріїв. Тому основна проблема при розв'язанні задач БО - формалізація принципу оптимальності. У разі відсутності «ідеального розв'язку» в задачі БО шукається компромісне рішення.

Для всякої альтернативи $X \in D$ вектор із значень цільових функцій $(F 1(X), F 2(X), \ldots F n(X)) \in$ векторною оцінкою альтернативи. Векторна оцінка альтернативи містить, як правило, повну інформацію про оптимальність цієї альтернативи для особи, яка приймає рішення (ОПР). Порівняння будь-яких декількох можливих результатів замінюється порівнянням їх векторних оцінок.

Розв'язок такої багатокритеріальної задачі шукається у $n$ - вимірному просторі. Для того, щоб вектор розв'язку $X=\left(x_{1}, x_{2}, x_{3} \ldots, x_{n}\right)$ знаходився в одиничному гіперкубі необхідно нормувати значення цільових функцій до безрозмірних величин із діапазону від 0 до 1 , використовуючи наступний вираз:

$$
F n_{\text {нор.. }}\left(x_{n}\right)=\frac{F n\left(x_{n}\right)-\min F n}{\max F n-\min F n} .
$$

При відсутності обмежень виду $g\left(x_{1}, x_{2}, x_{3} \ldots, x_{n}\right) \leq b_{i}$, радіус-вектор із координатами $\vec{r}_{\max }=(1,1,1 \ldots, 1)$ або $\vec{r}_{\min }=(0,0,0 \ldots, 0) n$ - вимірного одиничного гіперкуба буде оптимальним розв'язком багатокритеріальної задачі. Довжина такого вектора буде своєрідним мірилом оптимальності розв'язку.

Математичну постановку задачі можна подати у наступному вигляді:

$$
F=t_{1} F 1+t_{2} F 2+t_{3} F 3+\ldots . .+t_{n} F n \rightarrow o p t
$$

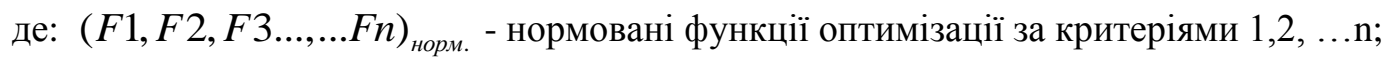
$t_{1}+t_{2}+t_{3}+\ldots . .+t_{n}=1$ - коефіцієнти пріоритетності оптимальності за кожним із критеріїв.

Зведемо поставлену багатокритеріальну задачу до множини однокритеріальних задач, причому із умовами:

- довжина вектора $X=\left(x_{1}, x_{2}, x_{3} \ldots, x_{n}\right)$ повинна прагнути до оптимуму (мініму/максиму);

- відношення довжини вектора-мірила до довжини вектора розв'язків повинно бути мінімальним;

- відношення довжини вектора-мірила до відстані між векторами $r_{o p t}$ i $r_{k}$ - прагне до максимуму;

- відношення відстані між векторами $r_{o p t}$ i $r_{k}$ до довжини вектору розв'язків повинно бути мінімальним.

Кожна із вище наведених умов має наступну властивість. Оптимальний вектор для кожної із вимог дасть «оптимальний по Парето» вектор розв'язку задачі (2). А виконання сукупності умов - 
дасть парето-оптимальний вектор рішення багатокритеріальної задачі за множиною однокритеріальних задач. Графічно така властивість інтерпретується як пошук вектора найбільш близького за якісними характеристиками до вектора-мірила (рис. 2).

Перед початком роботи із функцією багатокритеріальної оптимізації (2) слід виконати наступне:

1) виходячи із потреб виробництва, визначити складові функції цілі або критерії оптимізації;

2) визначити, індивідуальні для кожної функції $F n$ оптимізаційної задачі, необхідні параметри, обмеження і т. i.

Далі, на першому етапі, використовуючи спеціалізовані комп'ютерні програми розкрою, виокремлюється множина раціональних способів розкрою для конкретного виробничого випадку.

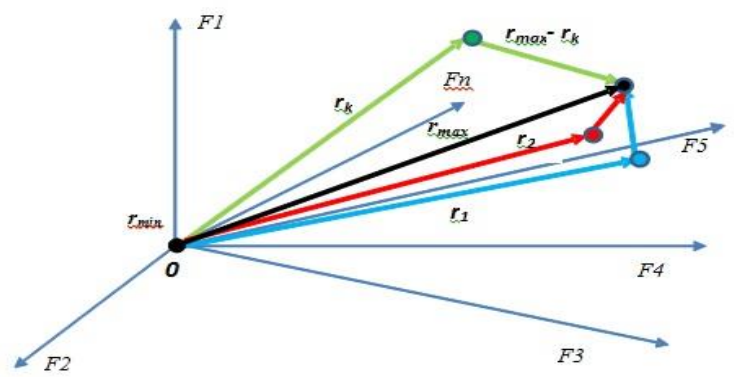

Рисунок 2 - Графічна інтерпретація пошуку вектора найбільш

близького до вектора-мірила у багатовимірному просторі

На другому етапі розв’язується комплекс задач лінійного програмування по визначенню інтенсивності використання раціональних карт розкрою за конкретним критерієм оптимізації.

$$
F n\left(\mathrm{x}_{n}\right)=a_{1} x_{1}+a_{2} x_{2}+\ldots . .+a_{k} x_{n} \rightarrow \min .
$$

Кожна така окрема задача зводиться до пошуку набору параметрів або вектору типу:

при обмеженнях

$$
x_{n}=\left(x_{1}, x_{2}, \ldots . . x_{n}\right) \text {, }
$$

$$
\left\{\begin{array}{l}
\sum_{j=1}^{n} a_{i j} x_{j} \leq b_{i}, \quad i=\overline{1, m} \\
\sum_{j=1}^{n} a_{i j} x_{j} \geq d_{i}, \quad i=\overline{1, m} . \\
x_{j} \geq 0, \quad j=\overline{1, n}
\end{array} .\right.
$$

Задачі такого типу можна розв'язувати симплекс-методом, в основі якого лежить принцип опорних базисних розв'язків, що теж інтерпретуються вершинами гіпер-багатогранників у багатовимірному просторі [13]-[16].

При знаходженні початкового базисного розв'язку, як правило, виходять із певних апріорних припущень відносно оптимальності вибору шуканих проектних параметрів $x_{n}$. А кількість ітерацій у симплекс-методі прямо залежить від міри «наближеності» початкового базисного розв’язку до оптимального.

Пропонується удосконалити процес вибору початкового базисного розв’язку для подальшого швидкого знаходження оптимальних значень проектних параметрів. Представимо постановку задачі у вигляді симплекс-таблиці виду: 
Таблиця 1 - Симплекс-таблиця оптимізаційної задачі

\begin{tabular}{|c|c|c|c|c|c|c|c|c|c|c|c|}
\hline & $x_{1}$ & $x_{2}$ & $\cdots \cdots$ & $x_{n}$ & $x x_{1}$ & $x x_{2}$ & $\cdots \cdots$ & $x x_{n}$ & $b_{n}$ & $d_{n}$ & $\delta$ \\
\hline$x x_{1}$ & $-a_{11}$ & $-a_{12}$ & $\cdots \cdots$ & $-a_{1 n}$ & 1 & 0 & $\cdots \cdots$ & 0 & $b_{1}$ & & \\
\hline$x x_{2}$ & $-a_{21}$ & $-a_{22}$ & $\cdots \cdots$ & $-a_{2 n}$ & 0 & 1 & $\cdots \cdots$ & 0 & $b_{2}$ & & \\
\hline$x x_{3}$ & $-a_{31}$ & $-a_{32}$ & $\cdots \cdots$ & $-a_{3 n}$ & 0 & 0 & $\cdots \cdots$ & 0 & & $-d_{1}$ & \\
\hline$\ldots \ldots$ & $\ldots \ldots$ & $\ldots \ldots$ & $\ldots \ldots$ & $\ldots \ldots$ & $\ldots \ldots$ & $\ldots \ldots$ & $\ldots \ldots \ldots$ & $\ldots \ldots$ & $\ldots \ldots$ & $\ldots \ldots$ & $\ldots \ldots$ \\
\hline$x x_{n}$ & $-a_{m 1}$ & $-a_{m 2}$ & $\cdots \cdots$ & $-a_{m n}$ & 0 & 0 & $\cdots \cdots$ & 1 & & $-d_{n}$ & \\
\hline$\square z \geq 0$ & $-c_{1}$ & $-c_{2}$ & & $-c_{n}$ & 0 & 0 & & 0 & 0 & 0 & \\
\hline
\end{tabular}

Розіб'ємо алгоритм на декілька етапів:

1. Вводимо у задачу додаткові змінні $x x_{1}, x x_{2}, \ldots . . x x_{n}$, кількість яких дорівнює кількості нерівностей, що описують обмеження, зводячи тим-самим задачу до канонічного виду.

2. На відміну від класичної постановки задачі, не будемо вимагати додатності правих частин перетворених рівнянь обмежень, а додаткові змінні беремо всі із додатними знаками. Додаткові змінні стануть основою для формування початкового базисного розв'язку.

3. Відтак процес скорочення від'ємних компонент базисного розв'язку будемо виконувати у такому порядку:

а) вибір роздільного стовпця. Його вибираємо, на відміну від «класики», відповідно до правила - $\sum_{1}^{m n} a_{m n} \min$ із елементів стрічок із від'ємними правими частинами вибираємо мінімальне значення;

б) вибір роздільної стрічки здійснюємо за правилом. Для $b \geq 0$ вибираємо найменше значення $b_{n} / a_{m n}$ роздільного стовпця. Для $b \leq 0$ вибираємо значення $b_{n} / a_{m n}$, яке найближче знаходиться до $\min b_{n} / a_{m n}$ роздільного стовпця.

Перетворивши таблицю методом Жордана-Гаусса, практично зразу отримаємо допустимий початковий базисний розв'язок. У більшості випадків такий підхід дозволяє одночасно змінити на додатні більшість правих частин рівнянь обмежень, що призводить до суттєвого скорочення кількості ітерацій симплекс-методу.

На третьому етапі розв'язання задачі багатокритеріальної оптимізації, виходячи із специфічних економічних i технологічних умов виробництва, встановлюються коефіцієнти пріоритетності $t_{1}, t_{2}, \ldots t_{n}$ за цілями оптимізації і знаходиться узагальнений розв'язок.

3 метою ілюстрації дієвості запропонованого підходу, розглянемо конкретний приклад. Для виготовлення 1 виробу, наприклад стола в університетський комп'ютерний клас, який спроектовано у програмі $P R O 100$, необхідно виготовити 7 деталей різної геометричної форми із плит ЛДСП. Фірмі із виробництва меблів замовлено 24 стола. На складі фірми у наявності є листи ламінованого ДСП у потрібній кольоровій гамі розмірами: 2440x1830мм, 1830x1500мм, 1830x1220мм.

Таблиця 2 - Специфікація плит ЛДСП

\begin{tabular}{|c|c|c|c|}
\hline п/п & Розміри ЛДСП & Вартість плити & $\begin{array}{c}\text { Кількість плит на } \\
\text { складі }\end{array}$ \\
\hline 1 & $2440 \times 1830 \mathrm{Mm}$ & 630 грн. & 10 \\
\hline 2 & $1830 \times 1500 \mathrm{Mм}$ & 440 грн. & 30 \\
\hline 3 & $1830 \times 1220 \mathrm{Mm}$ & 350 грн. & 16 \\
\hline
\end{tabular}

Обмеження наявності числа плит певного виду та розміру на складі виникають, виходячи із 3 економічних чинників, тобто вартості плити кожного типорозміру ЛДСП. бути:

Цілями для реалізації конкретної математичної моделі (критеріями оптимальності) можуть

1) мінімізація кількості цілих плит ЛДСП для реалізації замовлення;

2) мінімізація відходів за площею при розкрою ЛДСП для виконання замовлення;

3) мінімізація сумарної довжини ліній різу при розкрою ЛДСП; 
4) мінімізація вартості використаних плит ЛДСП для виготовлення замовлення;

5) мінімізація кількості різнотипних деталей на плиті ЛДСП при виготовленні замовлення.

Змінні - $x n_{1}, x n_{2}, \ldots x n_{k-1}, x n_{k}$ - число плит із різними розмірами розкроєними $k$ способом за критерієм $n$. Параметри - $Z_{1}, Z_{2}, Z_{3} \ldots Z_{n}$ - типи плит ЛДСП із різними розмірами, які можна використати для реалізації замовлення; $a_{1}, a_{2}, \ldots a_{k-1}, a_{k}$ - площа відходів після розкрою плити за визначеною, 3 використання, наприклад, програми Cutting, картою розкрою; $b_{1}, b_{2}, \ldots b_{k-1}, b_{k}$ сумарна довжина ліній різу для розкрою плити на деталі за визначеною, з використання програми Cutting, картою розкрою; $V_{1}, V_{2}, V_{3} \ldots V_{n}$ - вартість плити ЛДСП відповідного розміру; $\alpha_{1} Z_{1}, \alpha_{2} Z_{2}, \alpha_{3} Z_{3} \ldots \alpha_{n} Z_{n}$ - максимальна кількість кожного виду плити на складі.

Обмеження задачі. $x n_{1}, x n_{2}, \ldots x n_{j-1}, x n_{j}$ - цілі числа: число плит повинно бути цілим; $x_{1} \geq 0, x_{2} \geq 0, \ldots x_{j-1} \geq 0, x_{j} \geq 0$ - число плит для реалізації замовлення не може бути від'ємним.

Кількість кожної із деталей для виконання замовлення - $P$. Кількість деталей певного виду відповідно карти розкрою для плити із типорозмірами - $u_{n}$. Кількість плит певного типорозміру $K_{n}$.

Реалізація математичної моделі за сукупністю вибраних критеріїв відбувається наступним чином:

за критерієм 1 (мінімізація кількості цілих плит ЛДСП для реалізації замовлення)

$$
K_{n} x_{1}+K_{n} x_{2}+\ldots+K_{n} x_{k-1}+K_{n} x_{k} \rightarrow \min ;
$$

за критерієм 2 (мінімізація відходів за площею при розкрою ЛДСП для виконання замовлення)

$$
a_{1} x_{1}+a_{2} x_{2}+\ldots+a_{k-1} x_{k-1}+a_{k} x_{k} \rightarrow \min
$$

за критерієм 3 (мінімізація сумарної довжини ліній різу при розкрою ЛДСП)

$$
b_{1} x_{1}+b_{2} x_{2}+\ldots+b_{k-1} x_{k-1}+b_{k} x_{k} \rightarrow \min ;
$$

за критерієм 4 (мінімізація вартості використаних плит ЛДСП для виготовлення замовлення)

$$
V_{1} x_{1}+V_{2} x_{2}+\ldots+V_{k-1} x_{k-1}+V_{k} x_{k} \rightarrow \min
$$

за критерієм 5 (мінімізація кількості різнотипних деталей на плиті ЛДСП при виготовленні замовлення)

$$
r_{1} x_{1}+r_{2} x_{2}+\ldots+r_{k-1} x_{k-1}+r_{k} x_{k} \rightarrow \min
$$

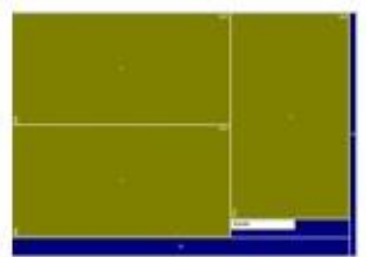

$x_{1}$

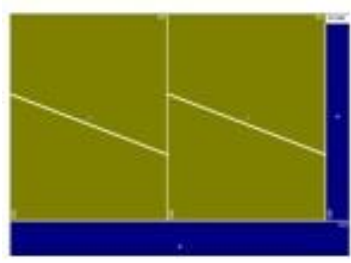

$x_{5}$

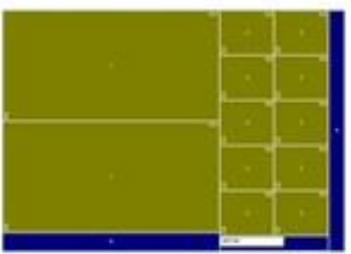

$x_{2}$

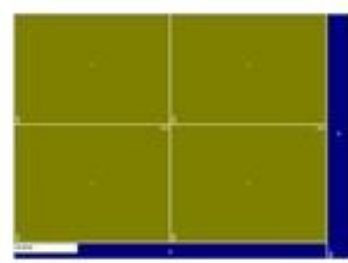

$x_{6}$

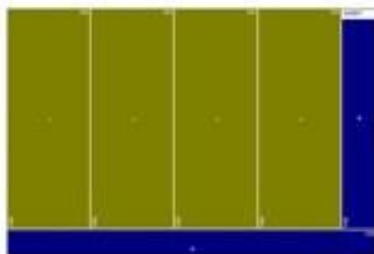

$x_{3}$

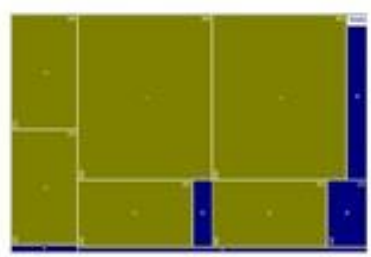

$x_{7}$

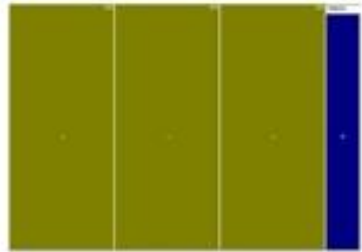

$x_{4}$

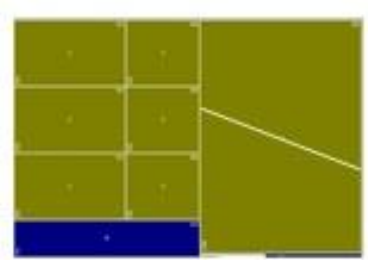

$x_{8}$

Рисунок 3 - Варіанти розкладки елементів на плитах ЛДСП 
У нашому прикладі було виокремлено 8 карт можливих варіантів раціонального розкрою листів ЛДСП, заданих розмірів, обчислених за допомогою програми Cutting, для виконання замовлення (рис. $3, \boldsymbol{x}_{\boldsymbol{1}}-\boldsymbol{x}_{8}$ ). В таблиці 3 наведено варіанти виходу окремих заготовок, та підраховані значення всіх коефіцієнтів для розв'язання одновимірних оптимізаційних задач за заданими критеріями.

Таблиця 3 - Варіанти розміщення елементів розкрою на листах ЛДСП

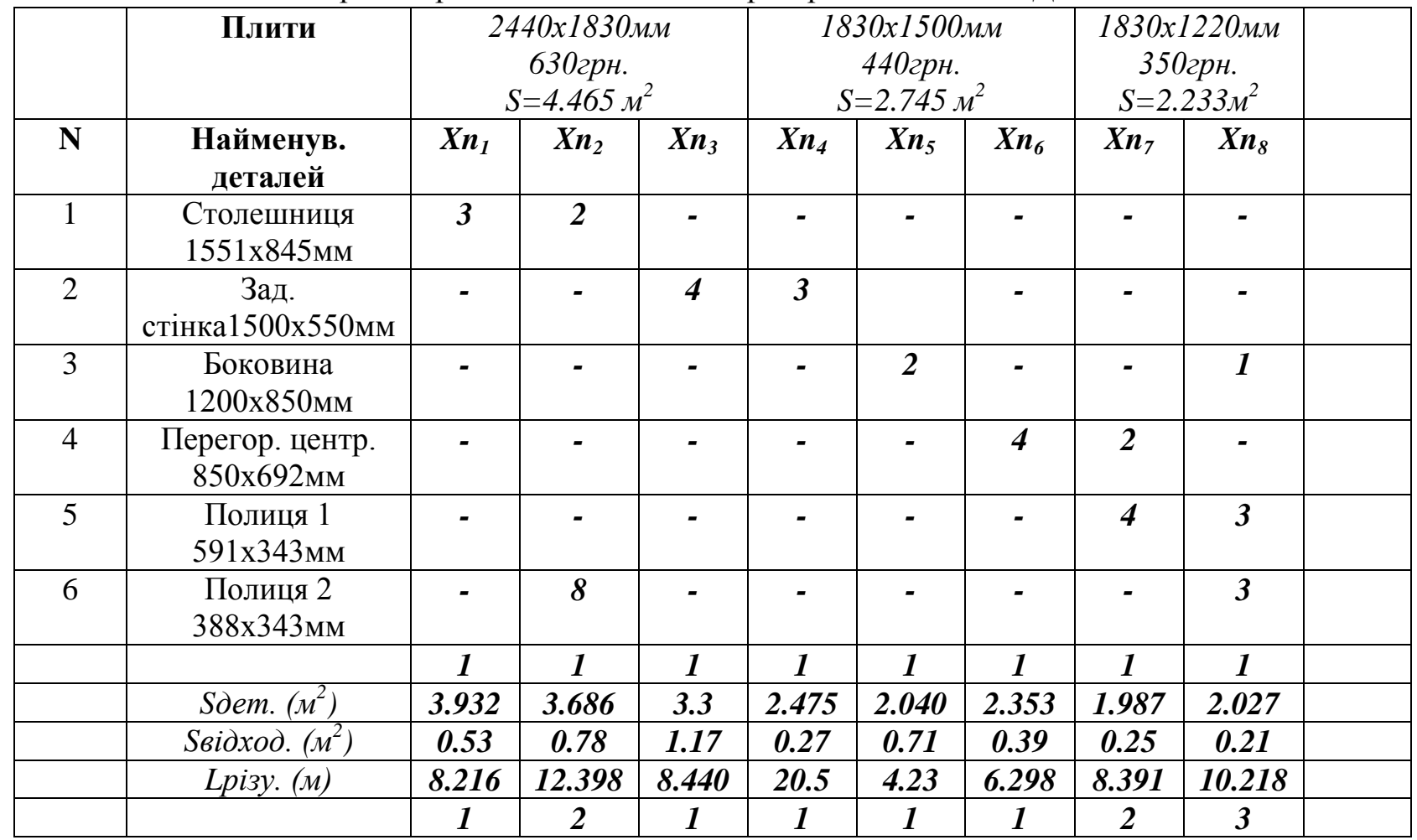

При цьому, система обмежень для оптимізації за кожним із вище наведених критеріїв набуде вигляду.

1. По випуску елементів стола:

$3 x_{1}+2 x_{2}=24,4 x_{3}+3 x_{4}=24,2 x_{5}+1 x_{8}=24,4 x_{6}+2 x_{7}=24,4 x_{7}+3 x_{8}=24,8 x_{2}+3 x_{8}=24$.

2. По запасам на складі плит визначеного розміру для розкрою:

$$
x_{1}+x_{2}+x_{3} \leq 10, x_{4}+x_{5}+x_{6} \leq 30, x_{7}+x_{8} \leq 16 .
$$

Використовуючи наведений вище підхід із удосконаленим алгоритмом вибору початкового базисного розв'язку, шукаємо симплекс-методом оптимальний план розкрою ЛДСП окремо за кожним із поставлених критеріїв (рис. 4).

Результатом обчислень стали два оптимальні набори розкрою плит за різними критеріями. Перший набір - 8,0,0,8,8,6,0,8, пов'язаний із використанням для повного виконання замовлення: 8 плит розміру 2440x1830 мм, 22 плити розміру $1830 x 1500$ мм і 8 плит розміру 1830x1220 мм. Друга оптимальна комбінація за іншими критеріями - 6,3,0,8,12,3,6,0: 9 плит розміру 2440x1830 мм, 23 плити розміру 1830x1500 мм і 6 плит розміру 1830х1220 мм. Слід зазначити, що на даному етапі геометричні параметри форми елементів, отриманих в результаті розкрою плит, не впливають на методику розв'язання задачі багатокритеріальної оптимізації.

Зводимо всі результати у таблицю 4 i, виходячи із завдань виробництва, визначаємо коефіцієнти важливості (пріоритети) для кожного із критеріїв оптимізації. Використовуючи (1), нормуємо значення цільових функцій для критеріїв 1-5. 
(ㄷ) Пустюльга С.І., Пуць В.С., Клак Ю.В. 2020

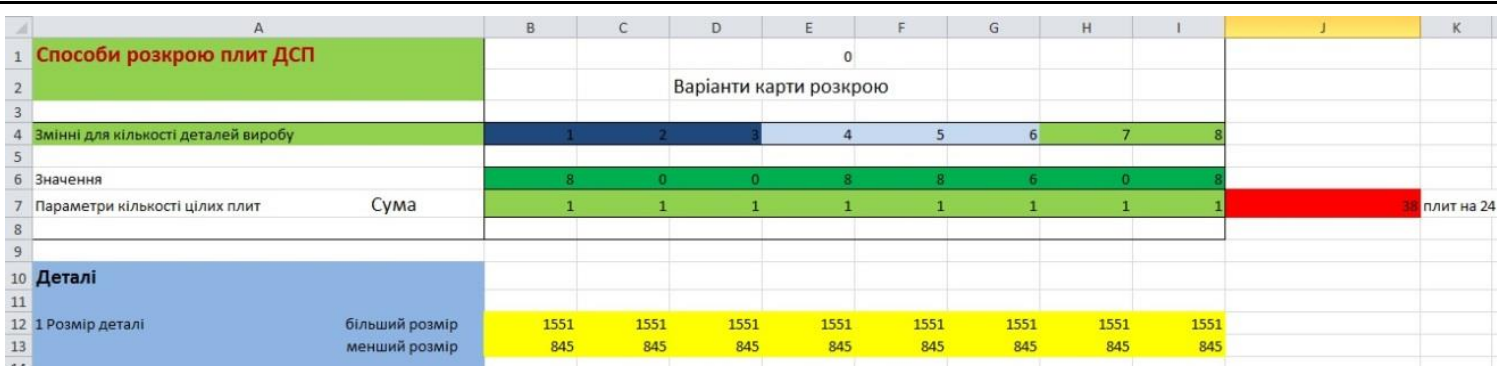

$\mathrm{a}$

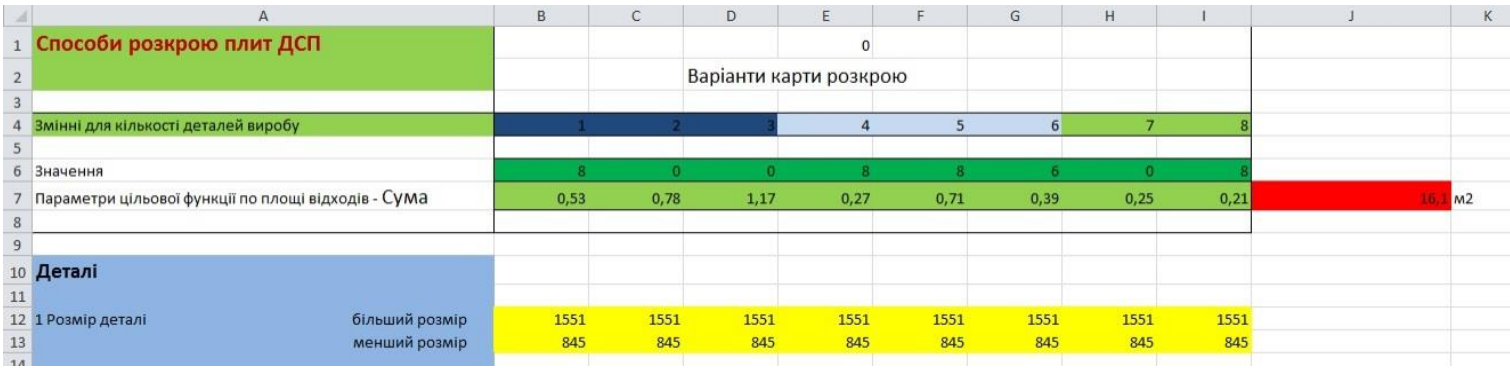

б

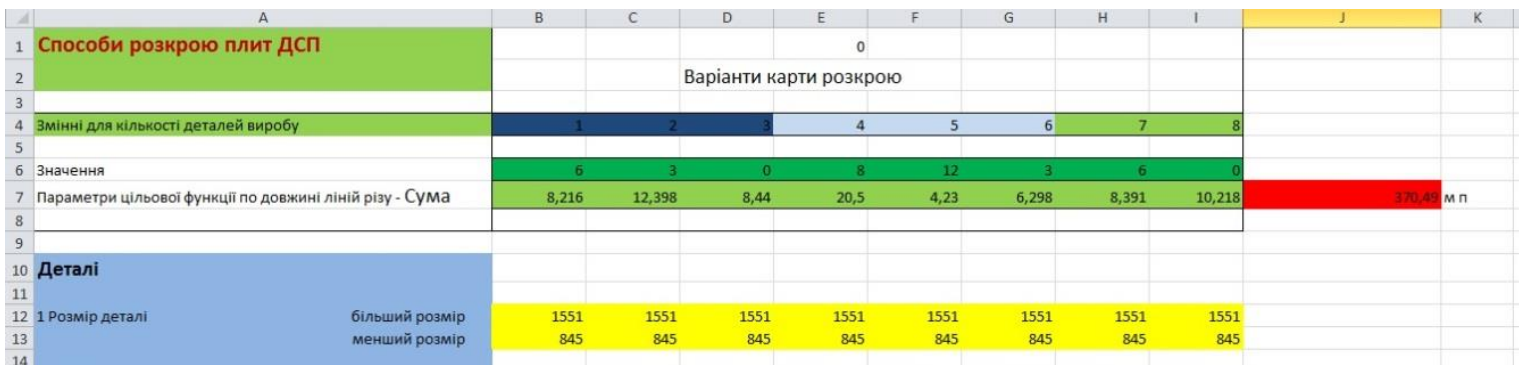

B

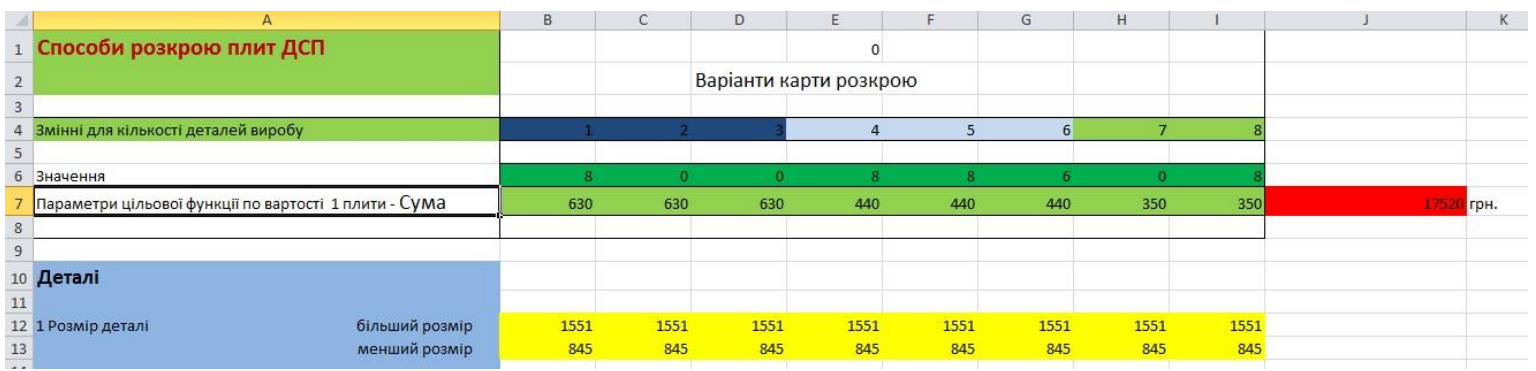

$\Gamma$

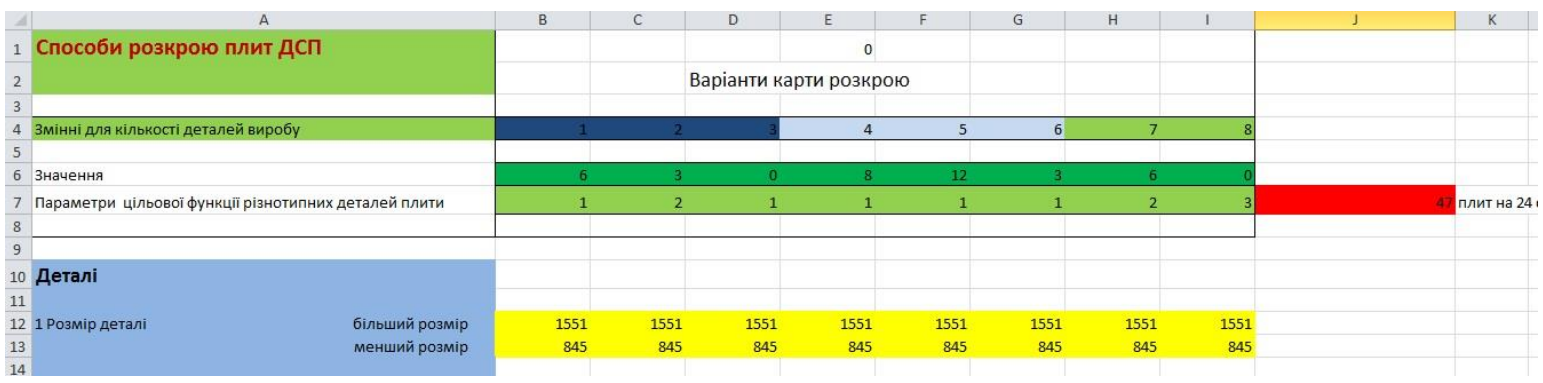

Д

Рисунок 4 - Варіанти оптимального розкрою окремо за кожним із критеріїв 
Таблиця 4 - Пріоритетність критеріїв багатокритеріальної оптимізації

\begin{tabular}{|c|c|c|c|c|c|c|c|}
\hline & $\begin{array}{c}\text { кість типів плит } \\
\text { для } \\
\text { оптимальної } \\
\text { розкладки } \\
\text { елементів }\end{array}$ & $\begin{array}{l}\text { по плит для } \\
\text { виконання } \\
\text { замовлення } \\
\text { горм }\end{array}$ & $\begin{array}{l}\text { пьна } \\
\text { площа } \\
\text { відходів } \\
\text { горм }\end{array}$ & $\begin{array}{l}\text { чьна } \\
\text { довжина } \\
\text { різі плит } \\
\text { норм }\end{array}$ & $\begin{array}{l}\text { вьна } \\
\text { вартість } \\
\text { сировини } \\
\text { оорм }\end{array}$ & $\begin{array}{l}\text { o плит } 3 \\
\text { мінімаль. } \\
\text { к-сть. } \\
\text { елем. } \\
\text { розкрою } \\
\text { норм }\end{array}$ & ритети \\
\hline $\begin{array}{c}3 a 1 \\
\text { крuтерієм }\end{array}$ & $8,0,0,8,8,6,0,8$ & $38 / 0$ & $16.1 / 0$ & $383.1 / 1$ & $17520 / 0$ & $54 / 1$ & $0.1 / 0.2$ \\
\hline $\begin{array}{c}3 a 2 \\
\text { критерієм }\end{array}$ & $8,0,0,8,8,6,0,8$ & $38 / 0$ & $16.1 / 0$ & $383.1 / 1$ & $17520 / 0$ & $54 / 1$ & $0.2 / 0.4$ \\
\hline $\begin{array}{c}\text { 3a } 3 \\
\text { критерієм }\end{array}$ & $6,3,0,8,12,3,6,0$ & $38 / 0$ & $18.87 / 1$ & $370.49 / 0$ & $17890 / 1$ & $47 / 0$ & $0.4 / 0.8$ \\
\hline $\begin{array}{c}3 a 4 \\
\text { крuтерієм }\end{array}$ & $8,0,0,8,8,6,0,8$ & $38 / 0$ & $16.1 / 0$ & $383.1 / 1$ & $17520 / 0$ & $54 / 1$ & $0.1 / 0.2$ \\
\hline $\begin{array}{c}3 a 5 \\
\text { критерієм }\end{array}$ & $6,3,0,8,12,3,6,0$ & $38 / 0$ & $18.87 / 1$ & $370.49 / 0$ & $17890 / 1$ & $47 / 0$ & $0.2 / 0.4$ \\
\hline
\end{tabular}

ОБГОВОРЕННЯ РЕЗУЛЬТАТІВ ДОСЛІДЖЕНЬ

Результати запропонованого підходу і проведених розрахунків показують, що розв'язок багатокритеріальної задачі оптимізації зводиться до пошуку вектора найбільш близького до еталону за якісними характеристиками та пріоритетністю. Для нашого конкретного прикладу він має вид:

$$
\begin{array}{cr}
F 1=0.1(0+0+1+0+1)+ & F 2=0.4(0+1+0+1+0)+ \\
0.2(0+0+1+0+1)+ & 0.2(0+1+0+1+0)=1.2 \\
0.1(0+0+1+0+1)=0.8 &
\end{array}
$$

Цей вектор базується на наборі елементів 6,3,0,8,12,3,6,0, що відповідає завданню багатокритеріальної оптимізації розкрою плит ЛДСП. Змінюючи пріоритетність критеріїв, ми тим самим можемо оперативно впливати на умови виробничих процесів підприємства.

\section{ВИСНОВОК}

У даній роботі, на основі аналізу стандартних етапів та можливостей відомих програм комп'ютерного розрахунку раціонального розкрою матеріалів, розроблено методику та алгоритми розв'язку задач багатокритеріальної оптимізації розкрою листів ЛДСП на елементи із різними геометричними параметрами для меблевих виробництв. Визначено особливості постановки та критерії задачі багатокритеріальної оптимізації, які дозволяють швидко і ефективно аналізувати якість отриманих на першому етапі карт розкрою, коригувати значущість і пріоритетність кожного із вибраних критеріїв оптимізації. Удосконалено алгоритм пошуку початкового базисного розв'язку задачі лінійного програмування, який суттєво скоротив кількість ітерацій в розрахунковій схемі та спростив процес розрахунку. Проведено комп'ютерну реалізацію розроблених алгоритмів.

\section{ПЕРЕЛІК ДЖЕРЕЛ ПОСИЛАННЯ}

1. Бабаев Ф.В. Оптимальный раскрой материалов с помощью ЭВМ / Ф.В. Бабаев; - М.: Машиностроение, 1982. - 168 с.

2. Мухачева Э. А. Прямоугольный раскрой в индивидуальном производстве / Э. А. Мухачева; В кн.: Математическое обеспечение расчетов линейного и прямоугольного раскроя. Материалы всесоюзного семинара. Уфа, 1981, - С. 108-118.

3.

Pisinger D, Sigurd M. Using decomposition techniques and constraint programming for solving the $t$ wo-dimensional bin-packing problem. INFORMS Journal on Computing 2007, - P. 36-51.

4. Young-Gun G, Kang MK. A new upper bound for unconstrained twodimensional cutting and packing. Journal of the Operational Research Society 2002, - P. 87-91. 5. Сергиенко И.В. Задачи дискретной оптимизации: проблемы, методы решения, исследования / И.В. Сергиенко, В.П. Шило; К.: Наук, думка, 2003.- 262 с. 
6. Stoyan Y. Functions for primary 2D-objects / Y. Stoyan, J. Terno, G. Scheithauer, N. Gil, T. Romanova ; Studia G.Informatica - 2002. - Vol. 2 (1). - P. 1-32.

7. Романова Т.Е. Математическая модель и метод решения задачи оптимизации упаковки произвольных двумерных объектов в прямоугольных областях /Т.Е. Романова, Е.А. Ступак, М.В. Злотник; Reports of the National Academy of Sciences of Ukraine. - 2009. - №1. - C. 48-53.

8. Milenkovic V. A monotonic convolution for Minkowski sums / V. Milenkovic, E. Sacks; International Journal of Computational Geometry and Applications. - 2007. - 17(4). - P. 383-396.

9. Чуб І.А. Конструктивні особливості задачі розміщення геометричних об'єктів в анізотропній області / І.А. Чуб; Прикладна геометрія та інженерна графіка. - 2008. - Вип. 80. - С. 139-143.

10. Балабанов В.Н. Многокритериальная задача рационального планирования продольного раскроя рулонного материала / В.Н. Балабанов; Проблемы информационных технологий. - 2009. №2 (6). - C.57-63.

11. Mukherjee I. A review of optimization techniques in metal cutting processes / I. Mukherjee, P. Ray; Computers and Industrial Engineering. - 2006. - Vol. 50(1). - P.15-34.

12. Wascher G. An improved typology of cutting and packing problems / G. Wascher, H. Haubner, H. Schumann; European Journal of Operational Research. - 2007. -Vol. 183. - P. 1109-1130.

13. Математические методы в программировании: Учебник. - М.: ИД «ФОРУМ»: ИНФРА-М, 2006. - 224 c.

14. Введение в исследование операций. 6-е издание: Пер. с англ. - М.: Издательский дом «Вильямс», 2001. - 912 с.

15. Кремер Н.Ш. Исследование операций в экономике: Учебное пособие для вузов / Н.Ш. Кремер, Б.А. Путко, И.М. Тришин, М.Н. Фридман; Под ред. проф. Н.Ш. Кремера; - М.: ЮНИТИ, 2001. $-407 \mathrm{c}$.

16. Ашманов С.А. Линейное программирование / С.А. Ашманов; - М.: Наука. Главная редакция физико-математической литературы, 1981. - 340 с.

17. Пустюльга С.I. Математична модель “м'якої оптимізації” процесу вибору легкового автомобіля відповідно прийнятих критеріїв / С.І. Пустюльга, Л.С. Громко, В.П. Самчук; Науковий журнал «Сучасні технології в машинобудуванні та транспорті»- Луцьк: Луцький НТУ, 2015. - Вип. 3. - С. 41-52.

18. Пустюльга С.I. Знаходження парето-оптимальних розв'язків багатокритеріальних оптимізаційних задач / С.І. Пустюльга, Л.С. Громко, Ю.В. Клак; Наукові нотатки ЛНТУ. Луцьк: ЛНТУ, 2015. - Вип. 48. - С. 72-77.

\section{REFERENCES}

1. Babaev F.V. Optimalnyiy raskroy materialov s pomoschyu EVM / F.V. Babaev; - M.: Mashinostroenie, 1982. - $168 \mathrm{~s}$.

2. Muhacheva E. A. Pryamougolnyiy raskroy $\mathrm{v}$ individualnom proizvodstve / E. A. Muhacheva; V kn.: Matematicheskoe obespechenie raschetov lineynogo i pryamougolnogo raskroya. Materialyi vsesoyuznogo seminara. Ufa, 1981, - P. 108-118.

3. Pisinger D., Sigurd M. Using decomposition techniques and constraint programming for solving the two-dimensional bin-packing problem. INFORMS Journal on Computing 2007, - P. 3651.

4. Young-Gun G., Kang M. A new upper bound for unconstrained two-dimensional cutting and packing. Journal of the Operational Research Society 2002, - P. 87-91.

5. Sergienko I.V. Zadachi diskretnoy optimizatsii: problemyi, metodyi resheniya, issledovaniya / I.V. Sergienko, V.P. Shilo; K.: Nauk. dumka, 2003.- 262 s.

6. Stoyan Y. Functions for primary 2D-objects / Y. Stoyan, J. Terno, G. Scheithauer, N. Gil, T. Romanova; Studia G.Informatica - 2002. - Vol. 2 (1). - P. 1-32.

7. Romanova T.E. Matematicheskaya model i metod resheniya zadachi optimizatsii upakovki proizvolnyih dvumernyih ob'ektov v pryamougolnyih oblastyah / T.E. Romanova, E.A. Stupak, M.V. Zlotnik; Reports of the National Academy of Sciences of Ukraine. - 2009. - S. 48-53.

8. Milenkovic V. A monotonic convolution for Minkowski sums / V. Milenkovic, E. Sacks; International Journal of Computational Geometry and Applications. - 2007. - 17(4). - P. 383-396. 
9. Chub I.A. Konstruktivni osoblivosti zadachi rozmischennya geometrichnih ob'ektiv v anizotropniy oblasti / I.A. Chub; Prikladna geometrIya ta Inzhenerna grafika. - 2008. - Vip. 80. S. 139-143.

10. Balabanov V.N. Mnogokriterialnaya zadacha ratsionalnogo planirovaniya prodolnogo raskroya rulonnogo materiala / V.N. Balabanov; Problemyi informatsionnyih tehnologiy. - 2009. 2 (6). - S.57-63.

11. Mukherjee I. A review of optimization techniques in metal cutting processes / I. Mukherjee, P. Ray; Computers and Industrial Engineering. - 2006. - Vol. 50(1). - P.15-34.

12. Wascher G. An improved typology of cutting and packing problems / G. Wascher, H. Haubner, H. Schumann; European Journal of Operational Research. - 2007. -Vol. 183. - P. 11091130.

13. Matematicheskie metodyi v programmirovanii: Uchebnik. - M.: ID «FORUM»: INFRAM, 2006. - $224 \mathrm{~s}$.

14. Vvedenie $\mathrm{v}$ issledovanie operatsiy. 6-e izdanie: Per. s angl. - M.: Izdatelskiy dom «Vilyams», 2001. - $912 \mathrm{~s}$.

15. Kremer N.Sh. Issledovanie operatsiy v ekonomike: Uchebnoe posobie dlya vuzov /N.Sh. Kremer, B.A. Putko, I.M. Trishin, M.N. Fridman; Pod red. prof. N.Sh. Kremera; - M.: YuNITI, 2001. - 407 s.

16. Ashmanov S.A. Lineynoe programmirovanie / S.A. Ashmanov; - M.: Nauka. Glavnaya redaktsiya fiziko-matematicheskoy literaturyi, 1981. $-340 \mathrm{~s}$.

17. Pustyulga S.I. Matematichna model "m'yakoyi optimizatsiyi” protsesu viboru legkovogo avtomobilya vidpovidno priynyatih kriteriyiv / S.I. Pustyulga, L.S. Gromko, V.P. Samchuk; Naukoviy zhurnal «SuchasnI tehnologiyi v mashinobuduvannI ta transportI» - Lutsk: Lutskiy NTU, 2015. - Vip. 3. - S. 41-52.

18. Pustyulga S.I. Znahodzhennya pareto-optimalnih rozv'yazkiv bagatokriterialnih optimizatsiynih zadach / S.I. Pustyulga, L.S. Gromko, Yu.V. Klak; Naukovi notatki LNTU. Lutsk: LNTU, 2015. - Vip. 48. - S. 72-77.

\section{S. Pustiulha, V. Puts, Y. Klak. Multicriterion optimization will cut out flags for individual furniture production}

This work is sanctified to development of effective algorithms for the decision of multicriterion optimization tasks will cut out flags on enterprises from making of furnitures after an individual order.

Known far of the specialized programs will cut out, that are actively used on a furniture production. Practically all of them, in one or another measure, are the compatible programs of creation of maps will cut out, that combine in itself the optimality of location of contours of details in the set sizes of feedstock with necessary speed of calculations. In basis of work of these most programs approach is fixed from the use of certain mathematical algorithms that allow effectively to conduct cutting out with the least of wastes.

However, going out features exactly of single furniture production, it follows to admit such automated approach an optimal variant to forming of maps will cut out materials, that would allow to the producer to take into account most criteria of optimization of placing of elements, flexibly to manage priorities of importance of their account, to form optimal maps according to technological possibilities of equipment that works on this production (parameters are a dust, degree of freedom and turning of tables, presence of the special adaptations for fixing of folias and т. and.). Account of the above-mentioned productive functions none of the enumerated programs not able to provide.

In-process, on the basis of analysis of the standard stages and possibilities of the programs of computer calculation rational will cut out materials, methodology and algorithms of decision of tasks of multicriterion optimization are offered will cut out letters of flags on the elements of different geometrical form for the production of furnitures of individual order. The features of raising and criteria are certain tasks of multicriterion optimization, that allow quickly and effectively to analyse quality of the maps got on the first stage will cut out, to correct meaningfulness and priority each of the chosen criteria of optimization. The algorithm of search of initial base decision of task of the linear programming, that substantially shortened the amount of iterations in a calculation chart and simplified procedure of calculation is improved. Computer realization of the worked out algorithms is conducted. Efficiency of the offered methodology and algorithms is tested for the production of goods on an enterprise from making of furnitures after an individual order. 
Keywords: rational cutting out of materials, multicriterion optimization, Pareto-optimality of decision, linear programming, criteria of task of optimization.

ПУСТЮЛЬГА Сергій Іванович, доктор технічних наук, професор кафедри інженерної та комп'ютерної графіки Луцького національного технічного університету, e-mail: mbf.declutsk@gmail.com. http://orcid.org/0000-0001-7623-7803.

ПУЦЬ Віталій Степанович, кандидат технічних наук, завідувач кафедри галузевого машинобудування та легкої промисловості Луцького національного технічного університету, e-mail: gm@1ntu.edu.ua http://orcid.org/0000-0003-3164-6173.

КЛАК Юрій Володимирович, старший викладач кафедри інженерної та комп'ютерної графіки Луцького національного технічного університету, e-mail: y.klak@Intu.edu.ua. http://orcid.org/00000002-7359-0756.

Serhii PUSTIULHA, Doctor of Technical Sciences, Professor of Engineering and Computer Graphics department, Lutsk National Technical University e-mail: mbf.declutsk@gmail.com. http://orcid.org/00000001-7623-7803.

Vitaliy PUTS, Candidate of Technical Sciences, Head of the Department of Industrial Engineering and Light Industry of Lutsk National Technical University, e-mail: gm@lntu.edu.ua http://orcid.org/00000003-3164-6173.

Yurii KLAK, Senior Lecturer, Department of Engineering and Computer Graphics, Lutsk National Technical University, e-mail: y.klak@1ntu.edu.ua. http://orcid.org/0000-0002-7359-0756.

DOI: 10.36910/automash.v2i15.398 